\title{
Unveiling dietary lifestyle of a Joseon-era mummy by extracting isotopic information from hair and bone
}

\author{
Da Young Kang and Ji Young Shin ${ }^{\star}$ \\ Conservation Science Division, National Research Institute of Cultural Heritage, \\ 132 Munji-ro, Yuseong-gu, Daejeon 305-380, Korea \\ (Received August 10, 2012; Revised September 18, 2012; Accepted September 18, 2012)

\section{조선시대 회곽묘 출토 미이라의 안정동위원소 분석으로 생애 주기에 따른 식생활 변화 추적

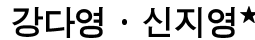 \\ 국립문화재연구소 보존과학연구실} \\ (2012. 8. 10. 접수, 2012. 9. 18. 수정, 2012. 9. 18. 승인)
}

\begin{abstract}
This study reports the stable carbon and nitrogen isotope of mummy, the preserved human time capsule from Joseon Dynasty. The stable isotopic composition of biological tissue is expected to be a direct and constant function of diet because the stable isotope ratios do not decay or change in abundance through time. Over the past three decades, stable carbon and nitrogen isotope analysis has been extensively applied for archaeological topics. However, this is the first case in Korean mummy to extract palaeodietary information using stable isotope analysis. We extracted isotopic information from bone collagen and hair keratin, which reflects the lifetime average diet and short-term diet, respectively. The average values of $\delta^{13} \mathrm{C}$ and $\delta^{15} \mathrm{~N}$ values are $-19.0 \%$ and $11.4 \%$ (bone collagen), and $-21.3 \%$ and $14.3 \%$ (hair keratin). Stable carbon isotope shows a mainly $\mathrm{C}_{3}$-based diet from cradle to grave. On the other hand, there is significant difference in stable nitrogen isotope which implies a relatively enriched diet before death. We expect this study opens up a potential to understand the palaeodietary lifestyle in Joseon Dynasty.

요 약: 미라는 뼈, 머리카락, 피부, 손톱 등 서로 다른 시기를 반영하는 생체 조직분석이 가능하며, 이 를 바탕으로 식생활, 환경 등 당시 생활상을 복원할 수 있는 매우 중요한 자료이다. 본 연구에서는 문경 흥덕동 회곽묘에서 출토된 조선시대 미라에서 추출한 빼 콜라겐과 머리카락 케라틴의 탄소와 질소 안정 동위원소 분석을 수행하였으며, 국내 출토 미라에 안정동위원소 분석을 적용한 첫 사례이다. 우리가 섭 취하는 식료의 종류에 따라 뼈와 머리카락 등 인체 조직에는 그 특유의 탄소와 질소 안정동위원소 정보 가 기록되며, 그 비율은 시간이 경과하여도 변하지 않는 것으로 알려져 있다. 특히 뼈에서 추출된 콜라 겐이라는 단백질은 생애 전주기의 평균 식생활을 추적할 수 있으며, 머리카락의 케라틴의 경우 길이에 따라 죽기 전 몇 달에서 몇 년의 식생활 정보를 담고 있다. 미라 조직의 안정동위원소 분석 결과 그 평
\end{abstract}

Corresponding author

Phone : +82-(0)42-860-9259 Fax : +82-(0)42-861-4928

E-mail : archsci@korea.kr 
균값은 다음과 같다(뼈 콜라겐 $\left(\delta^{13} \mathrm{C}=-19.0 \%, \delta^{15} \mathrm{~N}=11.4 \%\right.$ ), 머리카락 케라틴 $\left(\delta^{13} \mathrm{C}=-21.3 \%, \delta^{15} \mathrm{~N}=14.3 \%\right.$ ). 탄소 안정동위원소 값으로부터 생애 주기 동안 주로 $\mathrm{C}_{3}$ 작물 위주의 식생활을 하였다는 것을 예측할 수 있었으며, 특히 질소 안정동위원소 값의 경우 머리카락의 값이 뼈 콜라겐의 값보다 $2.9 \%$ 높게 나타난 것으로 미루어 볼 때 생애 전반에 걸친 영양 상태보다 죽기 전 몇 달 동안 육류 섭취 등으로 인한 단백 질 섭취량이 높았다는 것을 추정할 수 있었다.

Key words: bone collagen, hair keratin, Joseon-era mummy, palaeodiet, stable isotope analysis

\section{1. 서 론}

미라는 당시 질병, 식생활, 환경, 거주지 등 생활상 을 기록하고 있는 타임캡슐과 같은 매우 중요한 자료 이며, 국내외에서는 과거 생활상을 복원하기 위한 미 라 연구가 활발하게 진행되고 있다.

해외에서는 알프스 티롤 지역에서 발견된 5300년전 미라인 아이스맨 '외치(Ötzi)'의 발견으로 인해 미라 연 구가 더욱 활발하게 진행되었으며, 미라의 전체 게놈 서열의 해독으로 외치의 기원과 혈액형 연구, ${ }^{1-2}$ 외치의 장에 남아있는 잔존물의 DNA 분석 ${ }^{3}$ 및 방사선학적 분 석 ${ }^{4}$ 으로부터 그가 먹었던 마지막 식사에 관한 추정, 외 치의 빼에서 추출한 탄소, 산소, 스트론틈 동위원소와 미량원소 분석으로 외치의 마지막 주소, 거주지에 관한 연구 $^{5}$ 등 다각적인 관점에서 연구가 수행되었다. 이 외 에도 페루 아야쿠초(Ayacucho) 유적에서 발견된 미라의 뼈, 피부, 근육의 탄소·질소 안정동위원소 분석으로 당 시 식생활과 생계경제의 추정, ${ }^{6}$ 페루 출토 미라의 머리 카락과 손톱 케라틴 탄소 - 질소 안정동위원소 분석으로 계절성, ${ }^{7}$ 이동성에 따른 식생활 변화 연구 ${ }^{8}$ 등 고식생활 연구 역시 활발하게 진행되고 있다.

국내에서는 조선시대 회곽묘 출토 미라를 중심으 로 본격적인 연구가 시작되었고, 양주군에서 발견된 단웅 미라의 경우 머리카락의 형태적 보존 원인과 분 석, ${ }^{9}$ 치아 분석으로 연령 추정, ${ }^{10}$ 방사성 탄소 연대 측 정, ${ }^{11}$ 유전자 분석, ${ }^{12}$ 병원균 유전자 검출 ${ }^{13}$ 등 다양한 분야에서 연구가 수행되었다. 이 외에도 신라시대 유 적에서 고기생충란 발견, ${ }^{14}$ 400년전 여성 미라에서 폐흡충층 발견 ${ }^{15}$ 등 고기생충학 분야에서도 활발한 연구가 진행되고 있다.

지금까지 우리나라에서 출토된 미라를 통해 고기 생충 연구, 복식사, 질병 등 의학적인 연구는 활발하 게 이루어져왔으나, 식생활 연구를 위해 직접 조직의 안정동위원소 분석을 수행한 사례가 없었기 때문에, 본 연구는 매우 의미 있는 시작이라 할 수 있다. 본
연구는 국내 출토 미라의 안정동위원소 분석을 시도 한 첫 사례로 뼈에서 추출한 콜라겐과 머리카락의 케 라틴 정보로부터 과거 식생활에 관한 정보를 복원하 고자 한다. 옛날 사람들이 섭취했던 음식은 그 시대 의 식생활, 생계 경제, 영양 상태, 환경, 질병, 계층 등 사회의 다양한 측면을 반영하고 있다. 특히 그 중 에서도 음식물을 섭취했던 사람 조직의 탄소와 질소 안정동위원소 분석을 통해 직접적인 식료 섭취에 관 한 정보 제공이 가능하다. 특히 미라의 경우 뼈뿐만 아니라 머리카락, 피부, 손톱 등 생애 기간 중 서로 다른 시기를 반영하는 조직의 분석이 가능하며, 생애 주기 동안 식생활 변화의 추적이 가능하다.

\section{1. 탄소-질소 안정동위원소 분석을 이용한 고식생활 연구}

동위원소는 그 미세한 질량의 차이로 인해 반응 속 도나 화학 결합에 차이를 나타내며, 동위원소의 비율 은 동위원소 분획(isotopic fractionation)이라 일컫는 화학적, 물리적, 생물학적 과정에 따라 달라진다. 사 람이나 동물 등 탄소와 질소를 포함하고 있는 생물체 의 경우 그들이 섭취한 음식이나 환경 등으로 인한 동위원소 분획 과정을 거치면서 그 특유의 신호를 갖 게 된다. ${ }^{16}$ 특히 안정동위원소의 경우 이론적으로는 시간이 지나도 그 비율이 변하지 않기 때문에 그 화 학 신호의 해석을 통해 당시의 식생활 복원이 가능하 다. 지난 35 년간 고식생활 연구 분야는 안정동위원소 분석 중에서도 특히 탄소와 질소 안정동위원소를 중 심으로 활발한 연구가 진행되어 왔다.

안정동위원소비는 국제표준시료를 기준으로 측정 되며, 무거운 동위원소와 가벼운 동위원소의 비율인 $\delta$ 값을 편차천분율(\%, parts per thousand)로 나타내고, 수식은 다음과 같다. 탄소 안정동위원소의 경우 VPDB(Vienna Pee Dee Belemnite), 질소 안정동위원 소의 경우 대기 중의 질소 가스(AIR)를 국제표준시 료로 사용한다. ${ }^{17}$ 
$\delta^{13} \mathrm{C}=\left[\left[\left({ }^{13} \mathrm{C} /{ }^{12} \mathrm{C}\right)_{\text {시료 }} /\left({ }^{13} \mathrm{C} /{ }^{12} \mathrm{C}\right)_{\mathrm{VPDB}}\right]-1\right] \times 1000$

$\delta^{15} \mathrm{~N}=\left[\left[\left({ }^{15} \mathrm{~N} /{ }^{14} \mathrm{~N}\right)\right.\right.$ 시료 $\left.\left./\left({ }^{15} \mathrm{~N} /{ }^{14} \mathrm{~N}\right)_{\mathrm{AIR}}\right]-1\right] \times 1000$

사람이 섭취하는 식료의 종류에 따라 뼈, 머리카락 등의 조직에는 그 특유의 안정동위원소 정보가 기록 되며, 그 비율은 시간이 경과하여도 변하지 않는 것 으로 알려져 있다. 사람 조직의 안정동위원소 분석으 로 고식생활을 복원하기 위해서는 우선 식료 물질과 이를 섭취한 사람의 조직 사이의 동위원소적인 관계 를 이해하는 것이 가장 중요하다. 현재까지 학계에서 인정받고 있는 식료와 이를 섭취한 사람 조직 사이의 관계는 1993년 진행된 두 연구 그룹(Ambrose and Norr 팀과 Tieszen and Fagre 팀 $)^{18-19}$ 의 유명한 동물 사육실험 결과에 의존하고 있다. 식료가 이를 섭취한 사람의 조직, 특히 뼈 콜라겐에 전달될 때 탄소 안정 동위원소는 약 $5 \%$, 질소 안정동위원소는 약 $3 \sim 5 \%$ 높아지며, 특히 질소 안정동위원소의 경우 식물, 초 식동물, 잡식동물, 육식동물 등 그 영양 단계가 올라 감에 따라 각 단계마다 역시 3 5\%o의 증가를 보인다 는 결과를 발표하였다. 현재까지 탄소 안정동위원소 값으로부터 $\mathrm{C}_{3}$ 식물(쌀, 보리, 밀, 콩 등), $\mathrm{C}_{4}$ 식물(조, 피, 기장 등), $\mathrm{CAM}$ 식물(파인애플 등) 등 광합성 경 로의 차이를 보이는 식물군의 분류, 담수산, 해산 식 료의 구분 등이 가능하다. 먹이 사슬에 따른 영양 단 계가 2 3\%o씩 증가하는 것으로 알려져 있는 질소 안 정동위원소 값으로부터는 식생활이 주로 채식인지 육식인지 예측할 수 있으며, 탄소와 질소 안정동위원 소 값으로부터 동물성 단백질이 육상 동물, 해산 어 패류, 민물 어패류 중 어느 종류로부터 섭취된 것인 지와 그 비중까지 추적하는 것도 가능하다. ${ }^{18-20}$

이처럼 지난 35 년간 안정동위원소 분석을 이용한 고식생활 연구 분야에 가장 많이 활용된 것은 뼈에서 추출한 type I 콜라겐이며, 이 단백질의 경우 다른 조 직에 비하여 상대적으로 잘 보존되며, 콜라겐의 질을 평가하는 체계적인 화학 지표가 존재하기 때문이다. 하지만, 뼈 콜라겐의 안정동위원소 정보는 전체 영양 소가 아닌 단백질 정보를 주로 반영하고 있으며, 단 백질 비율이 높은 어패류나 단백질 비율이 낮은 식물 의 경우 $\delta^{13} \mathrm{C}$ 값에 과대 또는 과소 반영될 가능성이 있기 때문에 뼈 탄산염, 콜레스테롤 등 전체 영양소 를 반영할 수 있는 조직에의 적용을 위한 방법론적 연구 또한 활발하게 진행되고 있다. ${ }^{21-24}$ 이 외에도 조 직의 전환 속도(turnover rate)가 다르기 때문에 어떤 조직을 분석했는가에 따라 어느 시기의 식생활 정보
를 반영하는가가 다른데, 뼈 콜라겐으로부터는 약 10 30 년 사이의 평균 식생활, 그리고 손톱과 머리카 락, 피부의 정보로부터는 죽기 전 며칠에서 몇 달 전 의 식생활 복원이 가능하다. ${ }^{7,25-26}$

앞서 언급한 바와 같이 빼 또는 머리카락의 안정동 위원소 분석으로 고식생활을 복원하기 위해서는 우 선 식료 후보 물질들이 유의미한 동위원소 비율 차이 를 나타내야 하며, 사후 매장 환경에서 유입된 것이 아닌 생존 시의 정보를 추출해야 하고, 이를 검증할 수 있는 질 평가지수(quality indicator)가 정립된 조직 에 적용해야 한다. 따라서 본 전제 조건이 충족되고, 식료가 이를 섭취한 사람의 조직에 기록될 때 동위원 소 적으로 어떠한 차이를 보이는지에 대한 충분한 이 해가 가능하다면, 당시 사람들의 식생활과 영양 상태 에 관한 정보를 복원할 수 있을 것이다.

\section{2. 실 험}

\section{1. 분석 대상 연구 자료}

본 연구의 대상은 문경 흥덕동 회곽묘에서 발견된

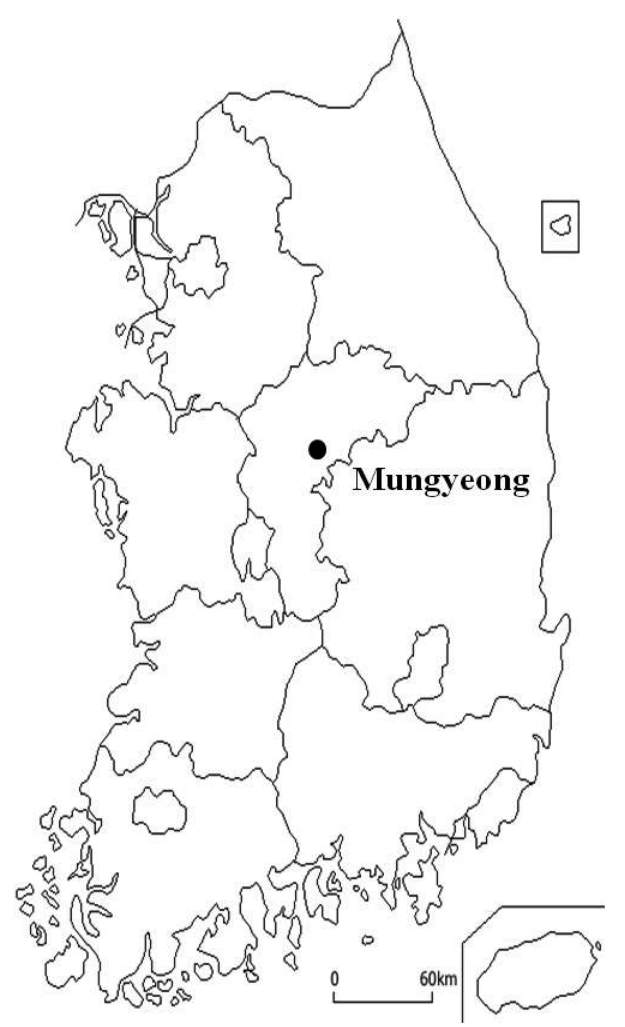

Fig. 1. Location of Mungyeong. 
미라이며(Fig. 1. 참고), 조선 시대 여성으로 전체적 으로 미라화되어 시신의 보존 상태는 양호하였지만, 발목 이하 부분은 부패되어 백골이 드러난 상태였다. 본 연구에서는 안정동위원소 분석을 위하여 미라의 뼈와 머리카락 일부를 채취하여 분석을 수행하였다. 미라의 머리카락과 비교 연구를 위하여 현대 여성의 머리카락을 기증 받아 분석을 진행하였다.

\section{2. 실험 방법}

\subsection{1. 뼈 콜라겐 추출}

절단한 뼈는 $0.5 \mathrm{M}$ 염산을 이용하여 무기물과 기 타 다른 단백질 등의 오염물을 제거하는 탈광화 (demineralization) 과정을 진행하고, $75{ }^{\circ} \mathrm{C}$ 에서 48 시 간 동안 $\mathrm{pH} 3 \mathrm{HCl}$ 을 이용하여 콜라겐 중 산에 녹지 않는 부분을 제거하였다. 그 후 5 8 $\mu \mathrm{m}$ Ezee filter를 이용하여 여과하는 젤라틴화(gelatinization) 과정을 거치고 마지막으로 냉동과 동결건조(lyophilization) 과정을 거쳐 최종적으로 정제된 콜라겐을 얻었다.

\subsection{2. 머리카락 전처리}

머리카락은 초순수(deionized water)에서 초음파 세 척(ultrasonic bath) 과정을 30 분 동안 진행한 후 클로 로포름(choloroform)과 메탄올(methanol)의 비율을 달리 하여, 각각 30 분씩 초음파 세척 과정을 진행하였다 (chloroform/methanol(2:1) 30 분 $\rightarrow$ methanol/chloroform (2:1) 30 분). 이 후 초순수를 넣고 초음파 세척을 30 분 간 진행하며, 이 과정을 총 2 회 반복하였다. 마지막 으로 세척된 머리카락 시료의 동결건조(lyophilization) 과정을 진행한 후 생애 주기에 따른 안정동위원소 분 석을 진행하기 위해 머리카락을 약 $1.5 \mathrm{~cm}$ 씩 잘라 서 준비하였다. ${ }^{27}$

\subsection{3. 머리카락의 표면 분석}

미라와 현대 여성 머리카락의 수직 단면을 부채꼴 모양으로 절단한 후 시편을 에폭시 수지로 고정한 다 음에 표면을 연마하여 관찰용 시료를 제작하였다. 금 도금(gold coating)을 한 다음 일본 Jeol사의 주사전자 현미경(JSM-5910LV)을 이용하여 $15 \mathrm{kV}$ 에서 이차전 자상(SEI)을 관찰하였다.

\subsection{4. 탄소·질소 안정동위원소 분석}

추출된 콜라겐과 케라틴은 안정동위원소 질량분석 기(Delta V Isotope Ratio Mass Spectrometer, Thermo Scientific)에 연결된 탄소 - 질소 원소분석기로 분석하
였다. 모든 시료는 2 회 분석한 평균값을 사용하였다. $\delta^{13} \mathrm{C}$ 와 $\delta^{15} \mathrm{~N}$ 은 각각 $\mathrm{VPDB}$ 와 $\mathrm{AIR}$ 의 국제표준시료를 기준으로 측정되어 편차천분 $(\%)$ 으로 표시하였으며, 분석 정밀도는 $\pm 0.2 \%$ 이다. 분석을 통해 얻은 $\delta^{13} \mathrm{C}$ 와 $\delta \delta^{15} \mathrm{~N}$ 값들 가운데 '콜라겐' 질 평가지수'('콜라겐' 수 율, 탄소와 질소의 비율 등)에 합격한 값들만 분석 결 과로 활용하였다. 머리카락의 경우 $\mathrm{C} / \mathrm{N}$ 값은 $3.0 \sim 3.8,{ }^{27}$ 뼈 콜라겐 ${ }^{28}$ 의 경우 $2.9 \sim 3.5$ 범위에 적용되는 분석값만 을 사용하였다.

\section{3. 결과 및 고찰}

\section{1. 머리카락의 표면 분석}

머리카락은 인체 조직 중에서 빼와 치아 다음으로 생물학적 분해가 서서히 진행되며, 매장된 피장자의 신체에 관한 중요한 정보를 얻을 수 있다. ${ }^{29}$ 미라는 오랜 매장 기간을 거치면서 조직이 손상되었을 것이 라 추정되며, 주사전자현미경(SEM)을 이용하여 머리 카락의 표면을 현대 여성 머리카락의 표면을 관찰하 였다(Fig. 2). Fig. 2에서 (1)과 (3)은 미라 여성의 머 리카락이며, (2)와 (4)는 현대 여성의 머리카락이다. (1)과 (2)는 머리카락의 수직 단면을, (3)과 (4)는 수 평으로 된 표면의 이미지를 보여준다. Fig. 2 를 보면 미라 여성과 현대 여성의 머리카락 모두 큐티클 층 표면에 비늘(scale)을 확인할 수 있으며, 미라의 머리 카락의 경우에도 비교적 손상정도가 심하지 않다는 것을 확인할 수 있었다. 하지만 미라 머리카락의 경 우 침착물들이 관찰되었으며, 현대 머리카락에 비해 그 두께가 가늘어진 것을 확인할 수 있었다.

\section{2. 탄소 - 질소 안정동위원소 분석}

미라의 생존 시 식생활을 복원하기 위해서 추출된 뼈 콜라겐과 머리카락 케라틴의 탄소 - 질소 안정동위 원소 분석을 진행하였다. 뼈 콜라겐의 경우 죽기 전 10 30년의 평균 식생활을, 유전적인 요인에 따른 차 이는 있지만 한달에 약 $1 \mathrm{~cm}$ 정도 자라는 것으로 알 려져 있는 머리카락 ${ }^{27}$ 의 경우 죽기 직전 몇달 동안의 식생활 변화 등 생애 주기에 따른 식생활 변화를 추 적하고자 하였다.

Fig. 3과 Table 1은 문경 흥덕동 출토 미라에서 추 출한 뼈 콜라겐와 머리카락 케라틴의 탄소와 질소 안 정동위원소 값을 보여준다. 문경 흥덕동에서 발견된 조선시대 여성 미라의 경우 뼈 콜라겐과 머리카락 케 라틴에 반영된 탄소 안정동위원소 값으로부터 주된 

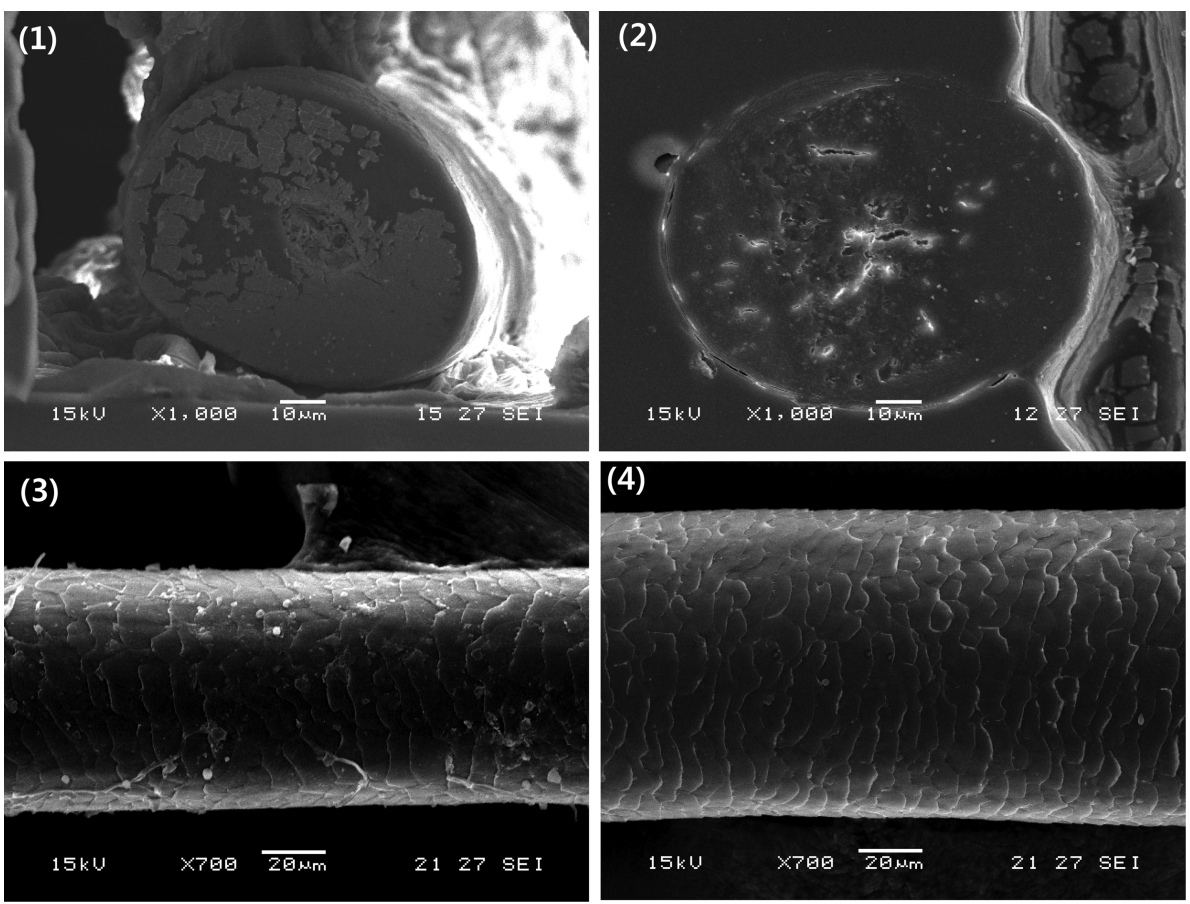

Fig. 2. A collection of scanning electron microscope images. (1) Cross section of hair shaft (mummy) (2) Cross section of hair shaft (modern woman) (3) Hair surface (mummy) (4) Hair surface (modern woman)

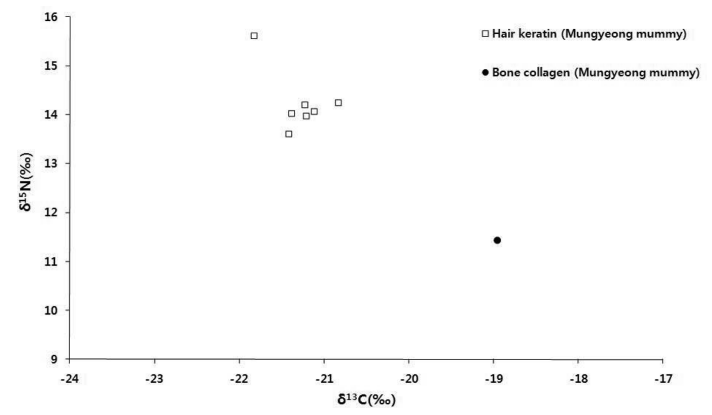

Fig. 3. Plot of $\delta^{13} \mathrm{C}$ vs. ${ }^{15} \mathrm{~N}$ values for bone collagen and hair keratin (mummy).

식료 후보물질이 $\mathrm{C}_{3}$ 식물(-34 -22\%o)군임을 알 수 있었 다. 이는 식료가 그 섭취자 조직에 반영되었을 때 약 $5 \%$ 의 탄소 안정동위원소 값이 높아진다는 것을 고려 한 결과이다. 질소 안정동위원소 값의 경우 머리카락 케라틴의 값이 뼈 콜라겐의 값보다 $2.9 \%$ 높은 결과를 나타냈으며, 이로부터 죽기 전 몇달 동안에 육류 섭취 등 영양 상태가 더 좋았을 것이라 추정할 수 있다.

Fig. 4에 본 연구 결과인 문경 흥덕동 출토 인골의 안정동위원소 분석 결과와 함께 기존에 강소영 등 30 에 의해 보고되었던 조선시대 서천 옥남리 출토 인골
Table 1. Stable carbon and nitrogen isotope results of bone collagen and hair keratin

\begin{tabular}{lccc}
\hline \hline \multicolumn{1}{c}{ Sample } & $\delta^{13} \mathrm{C}(\%)$ & $\delta^{15} \mathrm{~N}(\%)$ & $\mathrm{C} / \mathrm{N}$ \\
\hline $\begin{array}{l}\text { Bone collagen } \\
\text { (Mungyeong mummy) }\end{array}$ & -19.0 & 11.4 & 3.2 \\
$\begin{array}{l}\text { Hair keratin } \\
\text { (Mungyeong mummy) }\end{array}$ & -21.3 & 14.3 & 3.3 \\
$\begin{array}{l}\text { Hair keratin } \\
\text { (Modern woman 1) }\end{array}$ & -20.1 & 12.2 & 3.3 \\
$\begin{array}{l}\text { Hair keratin } \\
\text { (Modern woman 2) }\end{array}$ & -19.4 & 11.5 & 3.3 \\
$\begin{array}{l}\text { Hair keratin } \\
\text { (Modern woman 3) }\end{array}$ & -20.4 & 12.4 & 3.4 \\
$\begin{array}{l}\text { Hair keratin } \\
\text { (Modern woman 4) }\end{array}$ & -19.5 & 11.6 & 3.5 \\
\hline
\end{tabular}

의 결과를 함께 나타냈으며, 두 유적에서 출토된 뼈 콜라겐의 탄소와 질소 안정동위원소 값에서는 유의 미한 차이를 발견할 수 없었다. 문경 흥덕동 미라 추 출 콜라겐의 $\delta^{13} \mathrm{C}=-19.0 \%, \delta^{15} \mathrm{~N}=11.4 \%$, 서천 옥남 리 추출 콜라겐의 평균 $\delta^{13} \mathrm{C}=-20.2 \% 0, \delta^{15} \mathrm{~N}=11.5 \%$ 이다. 탄소 안정동위원소값에서 $1.2 \%$ 의 차이를 보이 나, $\mathrm{C}_{3}$ 식물군이 $-34 \%$ 에서 $-22 \%$ 범위에 분포하고, 또한 식물을 섭취한 사람에게 탄소 안정동위원소비가 


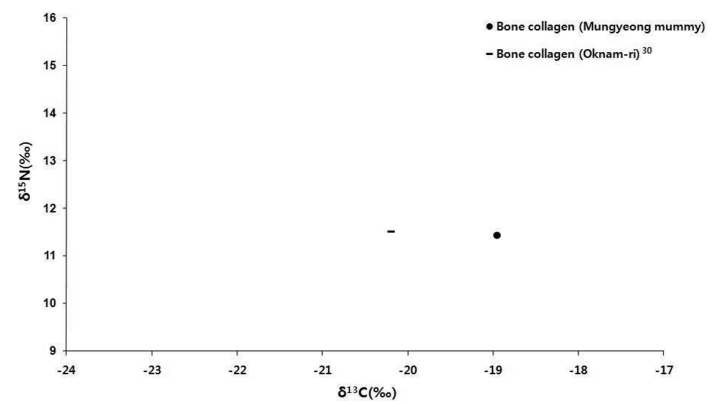

Fig. 4. Plot of $\delta^{13} \mathrm{C}$ vs. ${ }^{15} \mathrm{~N}$ values for bone collagen from Mungyeong and Oknam-ri site. ${ }^{30}$

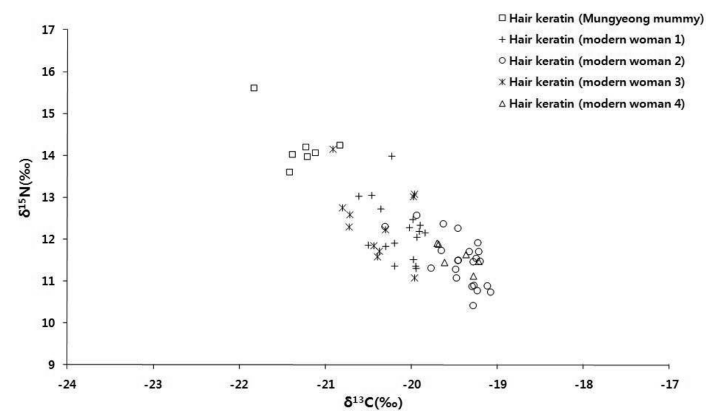

Fig. 5. Plot of $\delta^{13} \mathrm{C}$ vs. ${ }^{15} \mathrm{~N}$ values for hair keratin from Mungyeong mummy and modern woman.

전해질 때 약 $5 \%$ 의 차이를 보인다는 것을 감안할 때 모두 $\mathrm{C}_{3}$ 작물 위주의 식생활을 하였다고 추정된다.

본 연구 결과로부터 문경 흥덕동에서 출토된 미라 의 경우 생전에 $\mathrm{C}_{3}$ 식물과 육류를 주로 섭취하였다 고 추정할 수 있다. 이는 조선시대에 주로 쌀과 잡곡 등으로 밥을 지어먹었으며, 1500 년대 소의 갈비를 사 용하였고, 1800 년 대에서부터 쇠고기, 돼지고기, 오리 고기, 양고기 등 다양한 육류를 섭취하였다는 조선시 대 고문헌(조선무쌍신신요리제법, 농가십이월속시등) 과 고조리서에서도 확인할 수 있다 ${ }^{31}$.

마지막으로 Fig. 5의 현대 여성 4 명의 머리카락과 비교해 볼 때 탄소 안정동위원소 값에서는 유의미한 차이가 없으나, 질소 안정동위원소 값의 경우 미라의 $\delta^{15} \mathrm{~N}$ 값이 $2.9 \%$ 높았으며, 이는 물론 식습관과 개인 차가 존재하지만 문경 흥덕동에서 발견된 조선시대 여성의 경우 자원한 현대 여성 4 명에 비하여 한 단계 정도의 영양 단계가 높았음을 확인할 수 있었다.

\section{4. 결 론}

본 연구는 국내 출토 미라 조직의 안정동위원소 분
석을 시도한 첫 사례로 뼈에서 추출된 콜라겐과 머리 카락 케라틴 정보로부터 과거 식생활 정보를 복원하 고자 하였다. 특히 뼈에서 추출된 콜라겐이라는 단백 질로부터 생애 전주기의 평균 식생활을 추적할 수 있 으며, 머리카락의 케라틴의 경우 길이에 따라 죽기 전 몇 달에서 몇 년의 식생활 정보를 담고 있다. 문 경 흥덕동 출토 미라의 경우 빼 콜라겐 $\left(\delta^{15} \mathrm{~N}=11.4 \%\right.$ ) 과 머리카락 케라틴 $\left(\delta^{15} \mathrm{~N}=14.3 \%\right)$ 의 질소 안정동위원 소값에서 유의미한 차이를 나타냈으며, 이로부터 생 애 전반에 걸친 영양 상태보다 죽기 전 몇 달 동안 육류 섭취 등으로 인한 단백질 섭취량이 높았다는 것 을 추정할 수 있다. 또한 조선시대 고문헌과 고조리 서에서도 확인할 수 있듯이 쌀과 잡곡 등 $\mathrm{C}_{3}$ 식물과 육류를 주로 섭취하였다고 추정할 수 있으며, 본 연 구를 시작으로 국내에서 출토된 미라 조직의 안정동 위원소 분석으로 과거 식생활을 복원하는 연구 결과 들이 축적될 것이라 기대된다.

\section{감사의 글}

본 연구는 2012년도 국립문화재연구소 인턴연수과 정 지원 사업에 의해 이루어졌다. 또한 본 연구를 위 한 자료를 제공해 주신 국립경주문화재연구소, 문경 옛길박물관, 문경시 문화예술과, 연구 자료 수습과 채취에 도움을 주신 서울대학교 해부학교실, 문화재 보존과학센터, 전자현미경 분석에 도움을 주신 국립 문화재연구소 보존과학연구실 김소진 선생님께 감사 드린다.

\section{참고문헌}

1. L. Ermini, C. Olivieri, E. Rizzi, G. Corti, R. Bonnal, P. Soares, S. Luciani, I. Marota, G. D. Bellis, M. B. Richards and F. Rollo, Current. Biology, 18, 1687-1693 (2005).

2. A. Keller, A. Graefen, M. Ball, M. Matzas, V. Boisguerin, F. Maixner, P. Leidinger, C. Backes, R. Khairat, M. Forster, B. Stade, A. Franke, J. Mayer, J. Spangler, S. McLaughlin, M. Shah, C. Lee, T. T. Harkins, A. Sartori, A. M. Estrada, B. Henn, M. Sikora, O. Semino, J. Chiaroni, S. Rootsi, N. M. Myres, V. M. Cabrera, P. A. Underhill, C. D. Bustamante, E. E. Vigl, M. Samadelli, G. Cipollini, J. Haas, H. Katus, B. D. O'Connor, M. R. J. Carlson, B. Meder, N. Blin, E. Meese, C. M. Pusch and A. Zink, Nature Commun., 3, 698 (2012). 
3. F. Rollo, M. Ubaldi, L. Ermini and I. Marota, Proc. Natl. Acad Sci., 99, 12594-12599 (2002).

4. P. Gostner, P. Pernter, G. Bonatti, A. Graefen and A. R. Zink, J Archaeol Sci., 38, 3425-3431 (2011).

5. J. Hoogewerff, W. Papesch, M. Kralik, M. Berner, P. Vroon, H. Miesbauer, O. Gaber, K. Kunzel and J. Kleinjans, J. Archaeol Sci., 28, 983-989 (2001).

6. B. C. Finucane, J. Archaeol Sci., 34, 2115-2124 (2007).

7. J. S. Williams and M. A. Katzenberg, J. Archaeol Sci., 39, 41-57 (2012).

8. C. D. White, A. J. Nelson, F. J. Longstaffe, G. Grupe and A. Jung, J. Archaeol Sci., 36, 1527-1537 (2009).

9. 장병수, '남아 미라 및 출토유물 연구논총', p87-108, 단국대 석주선기념박물관, 2002.

10. 김종열, '남아 미라 및 출토유물 연구논총', p109-115, 단국대 석주선기념박물관, 2002.

11. 윤민영, '남아 미라 및 출토유물 연구논총', p171-186, 단국대 석주선기념박물관, 2002.

12. 신경진, '남아 미라 및 출토유물 연구논총', p117-134, 단국대 석주선기념박물관, 2002.

13. 김명주, 동양학, 40, 139-159 (2006).

14. D. H. Shin, C. S. Oha, T. Chung, Y. S. Yi, J. Y. Chai and M. Seo, J. Archaeol Sci., 36, 2534-2539 (2009).

15. D. H. Shin, C. S. Oha, S. J. Lee, E. J. Lee, S. G. Yim, M. J. Kim, Y. S. Kim, S. D. Lee, Y. S. Lee, H. J. Lee and M. Seo, J. Archaeol Sci., 39, 1103-1110 (2012).

16. L. Z. Gannes, C. M. Rio and P. Koch, Comp. Biochem Physiol., 119A, 725-737 (1998).

17. J. Höefs, 'Stable Isotope Geochemistry', $4^{\text {th }}$ Ed., SpringerVerlag, Berlin, 1997.
18. S. H. Ambrose and L. Norr, In 'Prehistoric human bone - Archaeology at the molecular level', J. B. Lambert, G. Grupe, Eds., p1, Springer-Verlag, Berlin, 1993.

19. L. Tieszen and T. Fagre, In 'Prehistoric human bone Archaeology at the molecular level', J.B. Lambert, G. Grupe, Eds., p121, Springer-Verlag, Berlin, 1993.

20. J. Y. Shin and J. J. Lee, J. Kore. Archaeological Soc., 70, 84-109 (2009).

21. S. Jim, S. H. Ambrose and R. P. Evershed, Geochim Cosmochim Acta., 68, 61-72 (2004).

22. J. Y. Shin and R. E. M. Hedges, J. Archaeol. Sci., 39(4), 1123-1130 (2012).

23. J. Y. Shin, Bull. Korean Chem. Soc., 32(1), 83-88 (2011).

24. J. Y. Shin, Bull. Korean Chem. Soc., 32(10), 3618-3623 (2011).

25. M. Stenhouse and M. Baxter, Nature, 267, 828-832 (1977)

26. S. Manolagas and R. Jilka, New Engl. J. Med., 332, 305-311 (1995).

27. T. C. O'Connell and R. E. M. Hedges, Am. J. Phys. Anthropol., 108, 409-425 (1999).

28. G. J. van Klinken, J. Archaeol Sci., 26, 687-695 (1999).

29. G. Y. Lee and B. S. Chang, Kor. J. Electron Microscopy, 35(4), 1-8 (2005).

30. S. Y. Kang, E. S. Kwon, E. J. Moon, E. M. Cho, M. S. Seo, Y. J. Kim and S. H. Jee, J. Conservation Sci., 26(1), 95-107 (2010).

31. H. J. Bok, Korean J. Food Culture, 22(6), 721-741 (2007). 